\title{
Den nasale luftveien hos astmatikere
}

\section{Astmatikere har en mindre nasal luftvei og opplever større grad av nese- tetthet enn ikke-astmatikere.}

Prevalensen av astma er økende både i Norge og på verdensbasis, og over $8 \%$ av den voksne norske befolkningen har astma. Så mange som 80-90\% av astmapasientene har symptomer og plager fra nese og bihuler. Allergisk rhinitt er en av mange risikofaktorer for utvikling av astma, og epidemiologiske studier har vist at rhinitt kan utvikles flere år før astmasymptomer manifesterer seg.

I mitt doktorgradsarbeid har jeg undersøkt nesen og bihulene til 100 astmapasienter og en kontrollgruppe bestående av 100 personer uten astma. Vi fant at astmatikere har et mindre nesevolum og et mindre tverrsnittsareal i nesen sammenliknet med kontrollgruppen. Astmapasientene hadde også fire ganger økt symptomskår på nesetetthet, $20 \%$ lavere maksimal luftstrøm gjennom nesen og signifikant redusert nese- og bihulerelatert livskvalitet. Pasienter med ikke-allergisk astma var like mye plaget som dem med allergisk astma.

Resultatene fra studien kan ha betydning for diagnostisering og behandling av de øvre luftveiene hos astmatikere. Pasienter med langvarig rhinitt bør undersøkes om de har astma, og astmatikere bør undersøkes om de har rhinitt og nesepolypose. Det er viktig å undersøke og behandle både de øvre- og nedre luftveiene slik at astmatikere får optimal medikamentell behandling av hele luftveissystemet og kirurgisk behandling av de øvre luftveiene når dette er nødvendig.

Wenche Moe Thorstensen

wenche.m.thorstensen@ntnu.no

\section{Kardiovaskulære risikofaktorer og venøs tromboembolisme}

\section{Det er ingen sammenheng mellom tradisjonelle risikofaktorer for atero- sklerose og venøs tromboembolisme.}

Selv om venøs tromboembolisme er en vanlig og alvorlig tilstand, opptrer opp til $50 \%$ av tilfellene uten åpenbare utløsende årsaker og det er derfor viktig å avdekke nye risikofaktorer. Nyere observasjonsstudier har vist en tydeligere sammenheng mellom arteriell trombose og venøs tromboembolisme enn tidligere antatt.

I mitt doktorgradsarbeid fulgte vi deltakerne i den fjerde Tromsø-undersøkelsen, der mer enn 27000 menn og kvinner deltok. Kardiovaskulære risikofaktorer ble registrert ved inklusjon og førstegangs venøs tromboembolisme og hjerteinfarkt registrert ut oppfølgingstiden (10,8-15,4 år).

$\mathrm{Vi}$ fant at alder og overvekt var risikofaktorer for både hjerteinfarkt og venøs tromboembolisme, mens kardiovaskulære risikofaktorer som mannlig kjønn, aterosklerose i halskar, diabetes, røyking, høyt blodtrykk, triglyserider og total-kolesterol samt lavt HDL-kolesterol, var assosiert med hjerteinfarkt, men ikke venøs tromboembolisme. Økende nivå av høy-sensitivt C-reaktivt protein (hs-CRP) ga ikke økt risiko. Ved fettbelastning hadde personer med tidligere venøs tromboembolisme lik distribusjon av lipider og lipoproteiner samt samme postprandiale lipemi som friske kontrollpersoner.

Våre funn taler mot en uavhengig assosiasjon mellom aterosklerose, aterosklerotiske risikofaktorer og venøs tromboembolisme. Den observerte assosiasjonen mellom arteriell og venøs trombose kan skyldes andre delte risikofaktorer eller være begrenset til manifest sykdom.

\section{Erin Mathiesen Hald}

erin.mathiesen.hald@unn.no

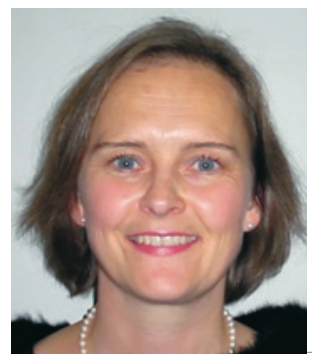

Wenche Moe

Thorstensen

Foto: Kari Lilleeng

Disputas

Wenche Moe Thorstensen disputerte for ph.d.graden ved Norges teknisk-naturvitenskapelige universitet (NTNU) 17. oktober 2014. Tittelen på avhandlingen er The nasal airway in asthmatics-from a structural, functional and subjective perspective.

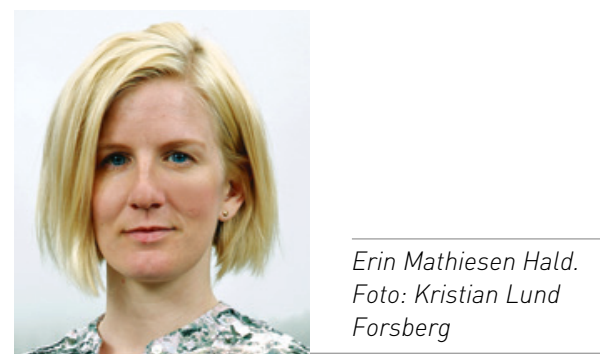

Disputas

Erin Mathiesen Hald disputerte for ph.d.graden ved Universitetet i Troms $\varnothing$ - Norges arktiske universitet 22.12. 2014. Tittelen på avhandlingen er Cardiovascular risk factors, atherosclerosis and venous thromboembolism. The Tromsø study. 